\title{
Trst (in Gorica) v blesteči luči trojezičnih operet
}

\author{
Luisa Antoni \\ Samostojna raziskovalka \\ Independent researcher
}

Prisotnost operete v Trstu in njegovi ožji ter širši okolici še ni bila celostno predstavljena: dosedanje muzikološke in sociološke študije so namreč prikazovale vsako nacionalno skupino posebej, čeprav vemo, da sta bila Trst in Gorica konec 19. in na začetku 20. stoletja pravi troživki v prepletanju italijanskega, slovenskega in nemškega jezika. Že v prejšnjih raziskavah sem dokazala, da je bila $\mathrm{v}$ Trstu pomembna prisotnost različno govorečih avtohtonih nacionalnih skupin, saj so $\mathrm{v}$ mestu složno sobivale vse tri velike evropske nacionalne skupine, in sicer italijanska, nemška in slovenska oz. slovanska, ${ }^{\text {I }}$ to pa je spodbujalo tekmovanje in iskanje najkakovostnejših kulturnih in glasbenih dogodkov.

Po prvi svetovni vojni, po razpadu avstro-ogrske monarhije in dodelitvi Trsta in Gorice Kraljevini Italiji je nemški delež tako rekoč izginil, prejšnja nacionalna trenja so prerasla $\mathrm{v}$ fašistični teror, ki je $\mathrm{v}$ dvajse-

1 Luisa Antoni, »Musica e coscienza nazionale degli Sloveni a Trieste e nella Venezia Giulia 1848-1927) «, v Cosmopolitismo e nazionalismo nella musica a Trieste tra Ottocento e Novecento, ur. Ivano Cavallini in Paolo Da Col (Trst: Quaderni del Conservatorio »G. Tartini«, 1999), 67-88; Luisa Antoni, »Mirk v Trstu«, v Mirkov zbornik, ur. Edo Škulj (Ljubljana: Družina, 2003), 47-67; Luisa Antoni, »Adamičeva tržaška leta", v Adamičev zbornik, ur. Edo Škulj (Ljubljana: Akademija za glasbo, 2004), 2539; Luisa Antoni, "Trieste-Trst-Triest, a cosmopolitan city«, v Musik-Stadt, Traditionen und Perspektiven urbaner Musikkulturen, ur. Helmut Loos (Leipzig: Gudrun Schröder Verlag, 2011), 402-11; Luisa Antoni, »Trieste and the surrounding areas «, v Musik und ihre gesellschaftliche Bedeutung nach 1945 (working title), ur. Rüdiger Ritter (Wiesbaden: Harrasowitz Verlag, 2020). 
tih letih uničil - tudi s fizičnim nasiljem - vse, kar v Trstu in Gorici ni bilo italijanskega.

Čeprav je bila v Trstu opereta v 19. in 20. stoletju v vseh treh jezikih, je muzikološko najbolj raziskana $\mathrm{v}$ italijanščini, predvsem zato, ker je bila po drugi svetovni vojni ta zvrst zorni kot, prek katerega se je razvilo nostalgično gledanje na avstro-ogrsko preteklost, za katero velja v Trstu splošni občutek, da je bila zlato obdobje za mesto. Starejša muzikološka generacija je gledala na opereto kot na izraz obdobja avtohtonega mitičnega Eldorada in šele $\mathrm{v}$ novejših raziskavah so opereta in njej sorodne zvrsti postavljene $\mathrm{v}$ širši zgodovinski, sociološki in muzikološki okvir, ki nam razkriva njene drugačne in seveda zanimivejše razsežnosti. ${ }^{2}$

Poudariti je treba, da se je med prvo in drugo svetovno vojno znatno zožila ponudba operet na zgolj enojezične, torej italijanske. Predvsem za Trst je bilo najbolj plodno obdobje trijezičnih operet pred prvo svetovno vojno, ki pa je še razmeroma neraziskano in ga bom tukaj obravnavala, ker je poznavanje tega obdobja nujno za njegovo zgodovinsko umestitev in za razumevanje dogajanja na tem območju v povojnem času.

\section{Širši in ožji zgodovinski okvir}

Intenzivnejši ekonomski in finančni razvoj Trsta in tržaškega pristanišča, ki je spodbujal priseljevanje prebivalcev tako $\mathrm{z}$ bližnjih kot bolj oddaljenih območij $\mathrm{v}$ mesto, se kronološko ujema $\mathrm{z}$ vzponom operete. $\mathrm{V}$ 19. stoletju in na začetku 2o. stoletja je tržaški meščanski sloj začutil potrebo po bogatejši kulturni ponudbi in s svojimi vsebinami jo je opereta nedvomno izpolnjevala.

Če pogledamo na svetovni razvoj te zvrsti, lahko ugotovimo, da je vezana na prvo pravo globalizacijo zahodne civilizacije, kar je poudaril tudi Tobias Becker.

The globalization of operetta was, first of all, directly connected to urbanization. The second half of the nineteenth century, we should recall, was an era of tremendous urban growth.

These new urban populations were not only looking for work and accommodation, they also wanted to be entertained. New spaces

2 Fabiana Licciardi, Theater-Kino-Varieté nella Prima guerra mondiale, l'industria dell'intrattenimento in una città al fronte: Trieste 1914-1918 (Trst: EUT edizioni Università di Trieste, 2019).

3 Tobias Becker, »Globalizing operetta before the First World War", The Opera Quarterly 33, št. 1 (2017): 7-27, https://doi.org/10.1093/oq/kbxo14. 
for entertainment were built, while old ones - among them theaters - proliferated.

A hundred years on, the most global 'operatic' genre was European operetta, in many senses a direct predecessor of the megamusical. Its heyday between the middle of the nineteenth century and the 1930 coincided with an era historians have described as the 'first age of globalization. ${ }^{4}$

V urbanizacijo mestnih središč se je vključil tudi Trst, ki je bil v teh letih edino pristanišče avstro-ogrskega cesarstva. K razvoju sta znatno prispevali dve pomembni dejstvi, in sicer podelitev statusa prostega pristanišča Trstu in odprtje Sueškega prekopa, po katerem so v Trst plule ladje z vsega sveta.

Z globalizacijo pa je $\mathrm{v}$ Trstu postala opereta tudi sredstvo, $\mathrm{s}$ katerim so skušali oblikovati zavest o nacionalni pripadnosti novih priseljencev in različno govorečih meščanskih tkiv, ki so sobivala v mestu sv. Justa. Ta dvojna narava spektaklov med globalizacijo in poudarjanjem nacionalne pripadnosti je dobila polemične odtise tudi v razpravi, ki se je vnela na straneh Edinosti in v katero sta bila vpletena Mirko Polič in Emil Adamič, ki sta na začetku 2o. stoletja sočasno živela in delovala v Trstu.

Mirko Polič, rojen v Trstu hrvaškemu očetu, ki se je preselil v mesto in deloval kot tiskar za časopis Edinost, je v mestu odraščal in se šolal na italijanskem konservatoriju, kar ga je oblikovalo v glasbenika in dirigenta. ${ }^{6}$

Emil Adamič pa se je kot novoporočenec s soprogo odločil, da se preselita iz Kamnika v Trst, ki se jima je takrat zdel pravo evropsko velemesto.? Tako kot Mirko Polič, Vasilij Mirk, Dušan Štular, bratje Dušan, Ivan Karlo in Belizar Sancin, Mario Šimenc in Srečko Kumar se je tudi Emil Adamič odločil za šolanje na italijanskem konservatoriju, kjer še danes hranijo njegov Preludij za orkester in Štiri sonate za violino in klavir.

Polič in Adamič pa sta bila zelo aktivna predvsem v slovenskem okolju. Polič je, skupaj z režiserjem Dragutinovićem, postavil na oder številne domače in tuje operete, vse do leta 1913, ko je - domnevno zaradi prepo-

4 Ibid., 8.

5 Polemiko bom obravnavala v naslednjih poglavjih.

6 Ciril Cvetko, Mirko Polič, dirigent in skladatelj (Ljubljana: Slovenski gledališki in filmski muzej, 1995).

7 Antoni, »Adamičeva tržaška leta«, 27-8. 
vedi oblasti, da uprizorijo Madame Butterfly v slovenščini ${ }^{8}$ - sprejel vabilo osiješkega gledališča in odpotoval. Adamič pa je v Trstu deloval kot učitelj, skladatelj, dirigent, glasbeni kritik in dopisnik ljubljanskih časopisov za Trst in okolico. Njegovo tržaško obdobje se je končalo na začetku prve svetovne vojne, ko so ga vpoklicali v vojsko.

\section{Vzpon operete $\mathrm{v}$ slovenščini in polemika med Emilom Adamičem in Mirkom Poličem}

Med raziskovalci, ki so se ukvarjali z opereto v Trstu, je tudi Marina Petronio, ki je opereti v italijanščini posvetila več člankov in knjigo. ${ }^{9}$ Petronieva $\mathrm{v}$ svojih raziskavah oblikuje hipotezo, da je opereta v evropskem prostoru vezana na posebne predstave v obliki t. i. farse oz. burke, razširjene po vsej Evropi, ki so jih uprizarjali razni regimenti; ti so namreč prek svojih godbenih dejavnosti v prvi polovici 19. stoletja večkrat ob koncertih ponujali občinstvu tudi t. i. Schwank ${ }^{10}$. V Trstu je bila glasbeno zelo aktivna godba 97. pešpolka, ki je večkrat sodelovala tudi pri raznih predstavah, vendar prava rekonstrukcija njenega delovanja, tako kot tudi delovanja drugih godb na tržaškem območju, še čaka na poglobljeno raziskavo.

Po letu 1814, tj. po odhodu francoskih vojakov, je kulturno življenje oživelo in lahko sklepamo, da so nemško govoreče potujoče skupine vključevale v svoje turneje tudi Trst in Gorico. Dela so črpali iz repertoarja dunajskih ljudskih gledališč in v Trstu je bil priljubljen predvsem Johann Nestroy, ki je s "praskajočo komičnostjo neusmiljeno razkrival človeško in družbeno hinavščino «" Tudi Petronieva omenja med prvimi predstavami, ki jih lahko razumemo kot operete, Lumpazivagabundus Johanna Nepomuka Nestroya. Leta 1840 jo je uprizorila skupina Börnstein v tržaškem Teatro Grande. To predstavo je posebno natančno opisal kritik Pacifico Valussi na straneh revije La Favilla. ${ }^{12}$ Podatkov o tem, ali so že prej nemško

8 Do danes ni bilo mogoče ugotoviti, od kod prepoved slovenske verzije Madame Butterfly. V tržaškem Gledališkem muzeju ni tega dokumenta, tako kot tudi ne v arhivih založniške hiše Ricordi. Ostajajo samo pričevanja senzacionalističnih člankov $\mathrm{v}$ Edinosti. Marina Petronio, L'operetta a Trieste... e altra musica d'intrattenimento (Trst: Luglio editore, 2010).

$10 \quad$ Ibid., 13.

11 Silvana de Lugnani, La cultura tedesca a Trieste dalla fine del 1700 al tramonto dell'Impero asburgico (Trst: Edizioni Italo Svevo, 1986), 39 (prevod avtorice).

12 Luisa Carrer, »La Favilla (1836-1846): giornale triestino di scienze, lettere, arti, varietà e teatri« (diplomska naloga, Univerza v Padovi, 1998-1999). 
govoreče skupine vključevale Trst in Gorico v svoje turneje, nimamo. Popolno sliko takratnega dogajanja bi osvetlili pregledi časopisnih člankov.

V Gorici je bila opereta priljubljena, $v$ mestnih gledališčih so jo izvajali od leta 1879. V Gorici so bila bolj kot v Trstu vidna nacionalna trenja, saj so imele italijanske potujoče skupine več uspeha kot nemške, vsaj do 9o. let. Pozneje so tudi v Gorici izvajali iste operete kot v Trstu.

Z zamikom nekaj desetletij so tako v Trstu kot Gorici tudi slovensko govoreči meščani dobili svoje operetne predstave. V drugi polovici 19. stoletja so po društvih, ki so imela svoje sedeže v podeželskih vaseh okrog $\mathrm{Tr}$ sta, prirejali burke, veseloigre in podobne zabave. Tudi za osvetlitev goriške scene bi za celostno podobo nujno potrebovali pregled člankov in novic iz takratnih časopisov.

Med prvimi znanimi predstavami je bil Ipavčev Tičnik, ki so ga leta 1884 uprizorili v tržaškem mestnem gledališču La Fenice v organizaciji Delavskega in Podpornega društva. ${ }^{13}$ Ob prehodu v novo stoletje je bila slovenska scena zelo živahna predvsem $\mathrm{v}$ domači produkciji. Pisatelj in dramatik Fran Govekar je naročil Viktorju Parmi, naj napiše scensko glasbo za Rokovnjače (1897) in Legionarije (1903), ki so bili v naslednjih letih večkrat uprizorjeni. Tudi podeželski slovenski odri na Tržaškem so ponujali ustvarjalno in poustvarjalno domačo produkcijo, taka sta npr. Vilharjeva »veseloigra v jednem dejanju « Poštena deklica ${ }^{\mathrm{I4}}$ v priredbi Pevskega društva Zarja v Rojanu in Dva gospoda, jeden sluga Hrabroslava Ražma ${ }^{\text {Is }}$ v priredbi Ženskega oddelka pevskega Društva Lipa v Bazovici. Predstave so postajale vse bolj kakovostne in odmevne ter so ustvarjale združevalne priložnosti, v katerih se je oblikovala slovenska in slovanska, takrat so jo imenovali slavljan$s k a$, narodna zavest. Največkrat so jih uprizorili v okoliških kulturnih domovih, ob pomembnejših priložnostih pa so najeli večja mestna gledališča. Po letu 1904, torej po odprtju Narodnega doma v središču mesta, se je glavno dogajanje osredotočilo na plese in prireditve v veliki dvorani te prestižne

13 Slovan 1, št. 7 (14. februar 1884): 53, http://www.dlib.si/?URN=URN:NBN:SI:doc-OAFEO8TH. O prisotnosti in priljubljenosti bratov Ipavcev na Tržaškem sem pisala v članku z naslovom Izvedbe Ipavčevih del na Tržaškem: Luisa Antoni, »Izvedbe Ipavčevih del na Tržaškem«, v Benjamin in Gustav Ipavec: zbornik prispevkov simpozija ob 10o. obletnici smrti Benjamina in Gustava Ipavca, ur. Primož Kuret (Šentjur: Knjižnica, 2009), 161-79.

14 Edinost (Trst) 26, št. 38 (15. februar 1901): 3, http://www.dlib.si/?URN=URN:NB$\mathrm{N}: \mathrm{SI}$ :doc-QW6RRRoV.

15 Edinost (Trst) 26, št. 79 (6. april 1901): 3, http://www.dlib.si/?URN=URN:NBN:SI:doc-BUQXoP6A. O Hrabroslavu Ražmu (1863-1908) imamo zelo malo podatkov: rodil se je v Bazovici in je vodil zbore v Barkovljah, kjer je bil tudi organist. 
večnamenske stavbe, ki jo je zasnoval arhitekt Maks Fabiani. V istih letih so tržaški velmožje ustanovili Dramatično društvo in Glasbeno matico, ki sta tudi dobila svoje prostore v Narodnem domu. Tako se je začelo najbolj uspešno obdobje glasbeno-scenskih uprizoritev tržaških Slovencev. Seznam uprizorjenih del, ki je še vedno nepopoln, kaže, da so domačo produkcijo bogatili tudi naslovi iz mednarodnega repertoarja operet, kar je pripeljalo do že omenjenih polemik med Emilom Adamičem in Mirkom Poličem. Adamiču je bilo do tega, da bi se počasi in vztrajno vzgajalo ljudstvo in krepilo njegovo narodno zavest, trinajst let mlajši Polič pa je meril predvsem na kakovost izvedenih del, pa čeprav so bili izvajalci ljubitelji.

V članku, ki je izšel v Edinosti 25. februarja 1910, je Adamič po kritiškem zapisu o koncertu Bruseljskega godalnega kvarteta dodal:

Ne zadostuje, da celo škoduje muzikalni izobrazbi mase, če hoče to ali ono pevsko društvo s prirejanjem obskurnih operet, ki se dajo $v$ dvomljivi pevski opremi, imponirati muzikalno nenaobraženim ljudem. Ti ljudje seveda niso slišali boljšega, zato jim je to višek umetnosti in njih navdušenje ne pozna mej. ${ }^{16}$

Polič je takoj naslednji dan poslal Edinosti dolg zapis, naslovljen »G. Adamiču in raznim zakulisnim kritikom «, v katerem odgovarja takole:

Prepričan sem bil, da prej ali slej pride odmev raznih zakulisnih kritik in zafrkacij o uprizoritvi operete "Mam'zelle Nitouche" $v$ javnost. Vendar pa nisem pričakoval, da se to zgodi $v$ taki formi in taki priliki (glej včerajš. "Edinost " pod: Književnost in umetnost). $Z$ di se pač, da gospoda niso mogli dobiti druge prilike, da bi povedali, kaj jih teži.

Pa naj bo kakorkoli: Čutim se prisiljenega, da podam nekoliko odgovora, da se ščisti obzorje.

Najprej naj zabeležim, da je g. Adamič še-le sedaj spoznal, da je »Mam'zelle Nitouche« »obskurna opereta«, menda ker se je predrznilo jo vprizoriti navadno pevsko društvo. Kolikor je meni znano, je ta "obskurna opereta " na repertoiru vseh boljših gledališč, ne izuzemši ljubljanskega, ter jo dajajo operetne družbe, ki pri-

16 Edinost (Trst) 35, št. 56 (25. februar 1910): 3, http://www.dlib.si/?URN=URN:NB$\mathrm{N}: \mathrm{SI}:$ doc-IAJ833UD. 
hajajo $v$ Trst, kot nekako posebnost in še celo rezano in skrajšano, kar mi seveda nismo storili. ${ }^{17}$

$\mathrm{Na}$ ta "nepričakovani odgovor" se je Adamič odzval in ob popravku, da Mam'zelle Nitouche res ni obskurna opereta, še enkrat poudaril to, kar je že zapisal:

Če bi se ti meseci, ti trudapolni večeri porabili v naštudiranje dobrih in naprednih zborov, zamogla bi Čitalnica napraviti marsikje lep utis ter si pridobiti povsodi (ne le pri njej) pogrešanih zaslug za našo slovensko pesem. Seveda, po mnenju g. Mirka Poliča, je "pošteno" vprizarjanje navadnih burk s petjem začetek $k$ poti do popularnih koncertov in muzikalni izobrazbi našega ljudstva.

[...] Tisti, ki bodo hodili po najinih grobeh, bodo sodili kdo je storil za povzdigo slovanske pesmi in muzikalne izobrazbe naše več: Vi, ali jaz! Trudite se tako, kakor se jaz in še bolj, kajti več časa in mladosti imate pred seboj, pa si bova dobra prijatelja. ${ }^{18}$

Verjetno je ta polemika razlog za dejstvo, da je leta 1911, ko je vseslovenski pripravljalni odbor zbiral sredstva za postavitev spomenika Benjaminu in Gustavu Ipavcu, čitalnica pri Sv. Jakobu pripravila novo uprizoritev Tič$n i k a$, pri kateri sta bila glavna pobudnika Adamič - ta je ob uprizoritvi imel tudi slavnostni govor ${ }^{19}$ - in takrat mladi Vasilij Mirk. V napovednem članku, ki nosi podpis V. M. (skoraj gotovo kratica za Vasilija Mirka), beremo:

To prvo domače delo je brez dvoma boljše nego marsikatera nemška ali francoska opereta, ki stopa po naših odrih. Uvažujemo vendar enkrat tudi svoje stvari, in ko teh ni več, naj pridejo na vrsto tuje. Ali ni čudno, oziroma značilno, da za Tičnika naši Slovenci niti ne vedo, da eksistira? ? $^{20}$

Kljub Adamičevim besedam in njegovemu trudu so slovenska društva v Trstu in okolici uprizarjala vse manj domačih operet in burk in vse več tujih operet. Ob Hervéjevi Mam'zelle Nitouche v slovenskem jeziku še že ome-

17 Edinost (Trst) 35, št. 57 (26. februar 1910): 3, http://www.dlib.si/?URN=URN:NB$\mathrm{N}: \mathrm{SI}:$ doc- $97 \mathrm{~S}_{5} \mathrm{~L} 7 \mathrm{PL}$.

18 Edinost (Trst) 35, št. 58 (27. februar 1910): 3, http://www.dlib.si/?URN=URN:NB$\mathrm{N}: \mathrm{SI}: \mathrm{doc}-\mathrm{UoDG}_{4} 8 \mathrm{~N} 9$.

19 Lida Debelli Turk, ur., Sv. Jakob, zgodovinski razgledi po življenju Slovencev v tržaškem delavskem okraju (Trst: Založništvo tržaškega tiska, 1980), 197.

20 Edinost (Trst) 36, št. 106 (16. april 1911): 3, http://www.dlib.si/?URN=URN:NBN:SI:doc-Q3 $\mathrm{FK}_{73} \mathrm{JC}$. 
njeno Lumpacij vagabund ali zanikrna trojica Johanna Nestroya, ${ }^{21}$ Pri belem konjiču (Im weissen Rössl) Benatzkega, Valčkov čar (Ein Walzertraum) Oscarja Strausa, Planquettovo Kornevilski zvonovi (Les cloches de Corneville), Zellerjevo Ptičar (Der Vogelhändler), Audranovo Punčka (La poupée), Kálmánovo Jesenski manevri (Ein Herbstmanöver), Lehárjevo Grof Luksemburški (Der Graf von Luxenburg), Fallovijevo Ločena žena (Die geschiedene Frau) in Dolarska princesinja (Die Dollarprinzessinen), Offenbachovo Lepa Helena (La belle Hélène), Jarnovo Logarjeva Krista (Die Försterchristl), Straussovo Netopir (Die Fledermaus) in Cigan baron ali Čevljar baron ${ }^{22}$ (Der Zigeunerbaron), Gilbertovo Čednostna Suzana ali Sramežljiva Suzana (Die keusche Susanne), Millöckerjevo Dijak prosjak (Der Bettelstudent), Eislerjevo Veseli soprog (Der lachende Ehemann), Jonesovo Gejša (The Giesha). Med domačimi operetami pa je ostal Ipavčev Tičnik, ponavljali pa so Legionarije in Vogričevo Moč uniforme. ${ }^{23} 31$. decembra 1909 so prvič uprizorili Parlament $v$ deveti deželi, »komično pevsko enodejanko za 5 moških glasov, moški zbor in orkester « Vasilija Mirka, ${ }^{24} 28$. januarja 1912 pa je zaživela tržaška praizvedba Parmove operete Caričine amaconke. ${ }^{25}$

O delovanju v prvem povojnem času imamo le nekaj skopih podatkov, saj se je začelo obdobje vzpona fašizma in posledično zaprtje društev, ki so tvorila osišče, skozi katero je rasla narodna zavest. V tem obdobju je škedenjsko društvo Velesila zaupalo Kazimirju Sancinu (1898-1976) v varstvo klavir mezzacoda, na katerem je nastala komična opera Casanova

21 Johann Nestroy, čigar dela so bila v Trstu zelo priljubljena, je celo dvakrat prišel v mesto, in sicer leta 1851 in 1858 . Lugnani, La cultura tedesca, 56. Po podatkih Neubauerja je bil Lumpacij Vagabund prvič uprizorjen v Ljubljani leta 1940. Prim. Henrik Neubauer, Opereta $v$ Sloveniji, zgodovinski pregled (Ljubljana: Glasbena matica, 2008), 152. Prevajalec tržaške verzije je bil Fran Gestrin, medtem ko je za ljubljansko izvedbo besedilo prevedel Niko Štritof.

$22 \mathrm{~V}$ Edinosti piše, da so predstavo začeli igrati pred sedmimi leti in da je tokrat (6. januarja 1909) v Narodnem domu 100. jubilejna uprizoritev. Edinost (Trst) 34, št. 6 (6. januar 1909): 1, http://www.dlib.si/?URN=URN:NBN:SI:DOC-R81HLO2.

23 Po zapisih Henrika Neubauerja je Vogrič predelal Vilharjevo Jamsko Ivanko leta 1895 in delo je po premieri v Tolminu imelo še različne izvedbe, med drugim tudi v Trstu in Gorici. Neubauer, Opereta $v$ Sloveniji, 150. Isti omenja tudi Vogričeve operete Lucifer (Trst, 1901), Prvi maj (Trst, 1901), Zgrešeno nadstropje (Tolmin, pred 1. svet. vojno) in Zlata bajka (Trst, 1906), vendar o tem ni bilo mogoče dobiti več podatkov.

24 Edinost (Trst) 34, št. 364 (31. december 1909): 2, http://www.dlib.si/?URN=UR$\mathrm{N}: \mathrm{NBN}: \mathrm{SI}:$ doc-QXWP7X1J.

25 Muzikološko odkritje te uprizoritve dolgujemo Darji Frelih. Darja Frelih, »Viktor Parma: raziskovalna izhodišča«, Muzikološki zbornik 29 (1993): 39-58, http://www. dlib.si/?URN=URN:NBN:SI:DOC-WYC4CCF7. 
po libretu Alberta Široka, predstavljena v Mariboru 16. aprila 1932. Nosilec glavne vloge je bil Belizar Sancin. ${ }^{26}$

Med podatki o medvojnih uprizoritvah je še ta, da so v pustnem obdobju šentjakobski pevci pod vodstvom Vlada Švare leta 1938 uprizorili Vodopivčevo spevoigro Kovačev študent v Gostilni na Lovcu. ${ }^{27}$

Fašistični pritisk je zadušil obetavno gledališče in mnogi so se izselili v Jugoslavijo ter tam naprej delovali, marsikateri Tržačan je emigriral v Maribor. ${ }^{28}$ Kljubovati je pomenilo postaviti svoje življenje na kocko, kot se je pokazalo v primeru Lojzeta Bratuža.

\section{Opereta v nemščini in italijanščini, domača ustvarjalnost, gostujoče italijanske in avstro-ogrske potujoče skupine}

Pri Slovencih je šlo predvsem za domačo poustvarjalno produkcijo, tako nemška kot italijanska opereta pa sta bili zastopani pretežno $\mathrm{z}$ gostujočimi skupinami in, po do danes najdenih podatkih, je bila izvirna domača produkcija zelo skopa. Edine domače operete, ki sem jih do zdaj zasledila, so Ricci-Stolzerjeva Don Chisciotte, ki jo je potujoča skupina Pietra Franceschinija predstavila skupaj z drugimi deli na tržaškem gostovanju med 18. marcem in 5. aprilom $1882^{29}$, in operete Il passaporto del droghiere, L'ope-

26 Prim. Martin Jevnikar, „Sancin Kazimir«, v Primorski slovenski biografski leksikon, vol. 13, ur. Martin Jevnikar (Gorica: Goriška Mohorjeva družba, 1987), 289, http:// www.sistory.si/cdn/publikacije/1-100o/269/Primorski_slovenski_biografski_leksikon_13.pdf. O mariborski predstavi piše Mariborski večernik "Jutra" (18. 4. 1932): "Gledališče je bilo skoraj razprodano, in navdušenje se je neprestano stopnjevalo, tako da sta morala navzoči komponist in libretist g. Albert Širok ponovno pred zastor. Prvi je prejel lep venec in mnogo cvetja. Opera je v marsikaterem oziru presenetila." Mariborski večernik "Jutra« 13, št. 87 (18. april 1932): 2, http://www.dlib.si/?URN=UR$\mathrm{N}: N B N: S I: D O C-R B F B L R E C$.

27 Lado Premru, »Slovensko petje pri Sv. Jakobu«, Jadranski koledar 1976, 223-33.

28 O dragoceni prisotnosti primorskih rojakov, ki so pribežali iz fašističnega Trsta v Maribor, podrobno piše Dragan Potočnik, »Primorski Slovenci v Mariboru 19181941«, Annales 21, št. 1 (2011): 55-70.

29 Luigi (Luigino) Ricci Stolz, sin neapeljskega skladatelja Luigija Riccija, se je rodil v Trstu leta 1852 in umrl v Milanu leta 1906. Original libreta operete Don Chisciotte, ki ga je tržaški tiskar Ludovico Herrman(n)storfer natisnil leta 1881, hrani washingtonska Library of Congress. Družina Herrman(n)storfer, ki je 37 let upravljala gledališče La Fenice v Trstu (za njimi so ga prevzeli Olimpio Lovrich, Strehler \& Co), je imela tudi svoje založništvo; Theodor je prijateljeval z Lehárjem, Kálmánom in je z drugimi člani družine (Francesco, Antonio in Gianni) prevajal v italijanščino operete Suppéja, Straussa idr. Licciardi, Theater-Kino-Varieté, 286. 
ra del maestro Pastrocci in A(t)tala pozabljene tržaške skladateljice Giselle Delle Grazie, ${ }^{30}$ ki je bila tudi impresarijka v Trstu v vojnem obdobju.

Iz teh podatkov lahko predpostavljamo, da je bila živa tudi italijanska domača produkcija, ki pa ni ostala v spominu oziroma bi jo morali podrobneje preučiti s pregledovanjem tiska.

Podatki o nemških predstavah segajo v leto 1784, ko je v Trstu gostovala nemška skupina Felixa Bernerja, impresarija, znanega po vsem cesarstvu po skupini, ki je štela 58 predvsem zelo mladih članov. ${ }^{31}$ Ostaja nam pričevanje, ko je v letu 1830 tržaška gospa, pripadnica nemškega meščanstva, zapisala v svojih spominih, da so »nemške predstave vedno polne, pa čeprav imajo Tržačani slabo mnenje o Nemcih «" ${ }^{32}$ V 6o. letih 19. stoletja so na tržaških odrih uprizarjali številne Offenbachove operete, takoj zatem Suppéjeve in Treumannove.

Posebej velja omeniti, da je v letih 1886 in $1887 \mathrm{v}$ Trstu nastopila tolminska primadona Gabrijela Mrak, ki se je uveljavila predvsem kot operetna pevka in je nastopala $\mathrm{v}$ različnih mestih avstro-ogrskega cesarstva. Na začetku leta 1887 je Mrakova kot članica dunajskega Carltheatra dobila vabilo za nastop v nemškem Stanovskem gledališču v Ljubljani. Ker je nastop preprečil požar v gledališču 17. februarja, je celoten ansambel odšel v Trst in tam požel velik uspeh. ${ }^{33} \mathrm{~V}$ Trstu so predstavili Millöckerjeva Začarani grad (Das verwunschene Schloss) in Gasparone, Straussovega Cigana barona (Der Zigeunerbaron), Dellingerjevega Don Cesarja, Straussovo Veselo vojno (Der lustige Krieg) in Lecocqov Giroflé-Girofla, Mrakova je pela v glavnih vlogah.

Potujoče skupine, ki so v Trstu in nekatere tudi v Gorici predstavljale operete, so bile številne, vendar vemo, da je ta seznam nepopoln: skupina bratov Grégoire, S. Spina, Pietro Cesari, Filippo Bergonzoni, Bruto Bocci, Antonio Scalvini, Pietro Franceschini, dunajska skupina Lori Strubel in nemška operetna skupina Bratislavskega gledališča, Raffaele Scognamiglio, francoska skupina Glaser, Gaspare Favi, Kraljeva operetna skupina iz Budimpešte, Carlo Lombardo, Mila Theren, Augusto Angelini, Tommaso Mauro, Amelia Soarez, Jole Baroni, Emma Vecla, Ferruccio Benini, du-

30 Fabiana Licciardi je na podlagi dnevniškega tiska poglobila njeno delo. Ibid., 447-8. Omenja jo tudi Mario Nordio, Il Politeama Rossetti di Trieste, storia di cinquant'anni 1878-1928 (Trst: Direzione del teatro, 1928), 45.

31 Lugnani, La cultura tedesca, 17.

32 Ibid., 39 (prevod avtorice).

33 Slavica Mlakar, Gabrijela Mrak, tolminska operna pevka (Tolmin: Knjižnica Cirila Kosmača, 1999), 28. 
najska skupina Paula Guttmanna, Calabresi-Sabbatini-Ferrero, Giovanni Emanuel, Carlo Fiorello, Angelo Cavallini.

Posebej velja omeniti, da so v Trstu predstavljali tudi zarzuele. Leta 1902 se je tam mudila španska skupina, na čelu katere je bil Tržačan Antonio Rupnik ${ }^{34}$; predstavili so se v Gledališču Rossetti z delom Certamen nacional in doživeli velik uspeh ${ }^{35}$ ter $\mathrm{z}$ delom El Maestro Campanon(e), to je predelava opere La prova di un'opera seria (1846) Giuseppeja Mazze (18061885), italijanskega skladatelja, ki je umrl v Trstu. ${ }^{36}$ Številne italijanske skupine so potem nadaljevale svojo pot $\mathrm{v}$ istrska in dalmatinska gledališča, na primer Pulj, Reko, Opatijo, Šibenik in Zadar, in tako utrjevale vezi, ki so jih ti teritoriji imeli z italijansko govorečim delom Trsta.

V tržaškem Gledališču Filodrammatico je bila 27. februarja 1907 v prisotnosti Suppéja in Kálmánna premiera Vesela vdova (Die lustige Witwe) pod taktirko Lehárja in z Milo Theren v vlogi Hanne. Vesela vdova je dve leti prej uspešno osvojila dunajsko občinstvo Theatra An der Wien. Okrog tržaške premiere se je vnela živa polemika in tako razdražila Lehárja, da je takoj po premieri odšel iz mesta in je druge ponovitve vodil Teply, kapelnik 97. pešpolka. Kot je podrobno poročal Runti, je pri libretu nastala težava zaradi narodnosti glavnega junaka Danila, saj naj bi predstavljal neko balkansko državo Pontevedro, za katero so protestniki ugibali, da je Črna gora. ${ }^{37} \mathrm{Na}$ Dunaju je opereta žela uspeh brez polemik, v Istanbulu pa so javno protestirali proti njej in $\mathrm{v}$ Trstu so se pojavili letaki v slabi italijanščini. ${ }^{38}$ Kljub temu je Lehárjeva vez s Trstom ostala neprekinjena, saj je bil Trst zanj - tako kot tudi za Suppéja - mesto, ki mu je bilo domače, kjer je živel v letih 1896 in 1898 in kjer je založniška hiša Carla Schmidta tiskala njegove li-

34 Nordio, Il Politeama Rossetti, 45.

35 Carlo Runti, Sull'onda del Danubio blu (Trst: Edizioni LINT, 1985), 94.

36 Zapleteno zgodbo okrog predelave Mazzovega dela La prova di un'opera seria $\mathrm{z}$ imenom El Maestro Campanon je razpletel Andrew Lamb, "Two Hundred Years of Maestro Campanone«, Zarzuela.net, 17. maj 2010, https://www.zarzuela.net/ref/feat/ campanone.htm.

37 Tako meni tudi Thobias Becker: "This plot was not particularly new: it was based on Henri Meilhac's farce L'attache d'ambassade (1861). While Meilhac made his impoverished country a vaguely German principality in his play, ,Pontevedro' in the operetta was obviously a satirical version of Montenegro, the smallest and poorest of the Balkan states. Inspired by this specific setting, Lehar looked to the folk music of the eastern parts of the Austrian-Hungarian Empire for inspiration, while at the same time also using contemporary dances from everywhere in the world, such as the Polonaise, the Kolo, the Valse, and the Cake Walk." Becker, Globalizing operetta, 11.

38 Runti, Sull'onda, 71. 
brete. Leta 1929 je Lehár spet obiskal Trst in v Gledališču Rossetti dirigiral svoji opereti Paganini in Federica.

Februarja 1917 je potujoča skupina impresarija Viktorja Eckardta izvajala v gledališču Eden nove operete, med njimi tudi tržaško praizvedbo Kálmánove Čardaške knjeginje (Die Cárdásfürstin), posebej pa velja omeniti, da je takrat orkester $\mathrm{z}$ velikim uspehom vodil komaj 17-letni Lovro von Matačić. ${ }^{39}$

Pred prvo svetovno vojno in med njo so v Trstu dobile izredni zagon dvorane, ki so gostile filme, operete, varieteje, tako imenovani Theater-Kino-Varietè. Predvsem v medvojnem času so se uveljavile kot gledališke agentke impresarijke ženske, ki so kazale posebno nagnjenje k organizaciji tovrstnih predstav (med njimi že omenjena Gisella Delle Grazie). Med impresariji naj omenim še Angela Curiela, Virginio Perini in Dalmatinca, deda Giorgia Strehlerja, Olimpija Lovricha, ki je živel in deloval v Trstu. Turneje filmov in potujočih operetnih skupin so presegale tržaške meje in se večkrat dotikale Reke, včasih Poreča in Pulja, poredkoma Zadra in Splita. Po prvi svetovni vojni je Trst prešel $\mathrm{k}$ Italiji in vezi $\mathrm{z}$ istrskimi in kvarnerskimi mesti so postale še bolj tesne.

Opereta $\mathrm{v}$ italijanščini je postala $\mathrm{v}$ Trstu v povojnem času zelo priljubljena, njen glavni spodbujevalec je bil Mario Nordio, ki je postal tudi uradni Lehárjev prevajalec za italijanščino.

Trst je postal mesto, kjer je opereta zelo priljubljena, in pomembna osebnost, kot je Mario Nordio, je pravi simbol sodelovanja med Lehárjem, našim mestom in opereto. Nordio je genialno prevedel Lehárja ob prvi italijanski predstavitvi Clo-Clo v gledališču Fenice leta $1924^{4 \circ}$

Naj dodamo, da je Nordio ob opereti Clo-Clo pripravil tudi ritmične prevode Lehárjevih operet Giuditta in Paganini, slednja je doživela italijansko premiero v Milanu leta $1925 .{ }^{4 \mathrm{I}} \mathrm{V}$ medvojnem obdobju je postala $\mathrm{v} \mathrm{Tr}$ stu priljubljena predvsem dunajska opereta $v$ izvedbi italijanskih potujočih skupin. Te so nastopale v mestnih gledališčih Rossetti, Filodrammatico, Armonia, Eden, Nazionale in La Fenice in predstavljale tudi izvirne operete italijanskih avtorjev, ki so se zgledovali po dunajski opereti, kot so Vir-

39 Il Lavoratore, 10. februar 1917.

40 Adriano Dugulin, »Il fascino dell'operetta«, v Tu che m'hai preso il cuor, l'operetta da Trieste all'Europa, ur. Adriano Dugulin (Trst: Občina Trst, 1994), 6 (prevod avtorice). 
gilio Ranzato (1883-1937), ${ }^{42}$ Carlo Lombardo (1869-1959), Pasquale [Cataldo Antonio] Mario Costa (1858-1933), Giuseppe Pietri (1886-1946) in Alfredo Cuscinà (1881-1955); podatki pričajo tudi o izvedbah Mascagnijeve operete Sì in Leoncavallove La reginetta delle rose. Ta je leta 1912 doživela svojo goriško praizvedbo. ${ }^{43}$

Ker so po letu 1925 začele pluti čezoceanske ladje iz Trsta v Severno in Južno Ameriko, je zelo verjetno, da so potujoče skupine in njihovi impresariji nastopali $\mathrm{z}$ istimi programi tudi na ameriških celinah. Tudi to poglavje še ni raziskano.

Ob koncu prvega pregleda prisotnosti operete $\mathrm{v}$ Trstu in mestih, ki so bila s Trstom povezana, bi omenila še operetni festival v Opatiji med letoma 1935 in 1938, ki je gostil skladatelje, kot so Franz Lehàr, Emmerich Kálmán, Robert Stolz in Miklós Brodsky. Sodelovali so tudi številni glasbeniki, povezani s Trstom. Festival so v navzočnosti avtorjev prvo leto v celoti posvetili Lehárju, drugo pa Kálmánu, tretje leto so predstavili Mascagnijevo $S i$ in sklenili z delom Roxy und ihr Wunderteam Ábraháma. Med tržaškimi umetniki, ki so bili na njem, naj omenim Guida Cergolija, ${ }^{44} \mathrm{ki}$ se je pozneje preselil v Italijo.

\section{Povojno obdobje}

Z glasbenega vidika sta postala Trst in Gorica v medvojnem času manj zanimiva, saj je živahno, večjezično in medkulturno prepletanje različnih operetnih in glasbenih skupin izginjalo in je ostala le italijanska ponudba. Iz do danes zbranih podatkov lahko upravičeno sklepamo, da so se konec 19. in na začetku 20. stoletja prepletale operetne ponudbe $\mathrm{v}$ različnih jezikih, kar je dajalo mestu Trst poseben čar ter vabilo in fasciniralo nove priseljence. Trst je bil obenem prava valilnica za številne umetnike, zlasti slovenske in slovanske. Nekateri so se iz mesta izselili iz službenih razlogov (na primer Viktor Parma), pozneje pa predvsem pod pritiskom prisilne ita-

42 Njegovi Cin-ci-là (1923) in Il paese dei campanelli (1925) sta še danes pravi zimzeleni uspešnici tržaških operetnih odrov.

43 Alessandro Arbo, Musicisti di frontiera (Gorica: Edizioni La laguna, 1998), 146.

44 Guido Cergoli (Trst, 1912-Rim, 20oo), brat bolj slavnega pesnika, novinarja in pisatelja Carolusa, se je rodil v družini, ki je bila po materini strani madžarskega in hrvaškega rodu, po očetovi pa slovenskega. Kot korepetitor je sodeloval na operetnem Festivalu v Opatiji. Po obdobju, v katerem je sodeloval kot pianist in s svojim orkestrom z Radiem Trieste, je dobil zaposlitev v Rimu. Prvič se je s svojim orkestrom predstavil na tržaškem radiu januarja 1936, takrat je bil ta del severnoitalijanske medijske mreže EIAR. Prim. Antoni, »Trieste and the surrounding areas«. 
lijanizacije, kot denimo Mirko Polič, Vasilij Mirk, bratje Dušan, Ivan Karlo in Belizar Sancin, Robert Primožič, Mario Šimenc, Ksenija Vidali, Ondina Otta, Jakov Cipci.

$\mathrm{V}$ Trstu je $\mathrm{v}$ prvem povojnem času polno zadihala italijanska opereta $\mathrm{z}$ italijanskimi potujočimi skupinami in bila nadvse uspešna tudi v drugem povojnem času in je prisotna še danes, čeprav manj.

Vsekakor je poglavje prisotnosti operete v Trstu in Gorici še razmeroma odprto in bo, če ga bo kdo od muzikologov res temeljito raziskal, prineslo zanimiva muzikološka odkritja.

\section{Bibliografija}

Antoni, Luisa. »Musica e coscienza nazionale degli Sloveni a Trieste e nella Venezia Giulia 1848-1927)《. V Cosmopolitismo e nazionalismo nella musica a Trieste tra Ottocento e Novecento, urednika Ivano Cavallini in Paolo Da Col, 67-88. Trst: Quaderni del Conservatorio »G.Tartini«, 1999.

Antoni, Luisa. "Mirk v Trstu«. V Mirkov zbornik, urednik Edo Škulj, 47-67. Ljubljana: Družina, 2003.

Antoni, Luisa. »Adamičeva tržaška leta«. V Adamičev zbornik, urednik Edo Škulj, 25-39. Ljubljana: Akademija za glasbo, 2004.

Antoni, Luisa. »Izvedbe Ipavčevih del na Tržaškem«. V Benjamin in Gustav Ipavec: zbornik prispevkov simpozija ob 1oo. obletnici smrti Benjamina in Gustava Ipavca, urednik Primož Kuret, 161-79. Šentjur: Knjižnica, 2009.

Antoni, Luisa. »Trieste-Trst-Triest, a cosmopolitan city«. V Musik-Stadt, Traditionen und Perspektiven urbaner Musikkulturen, urednik Helmut Loos, 402-11. Leipzig: Gudrun Schröder Verlag, 2011.

Antoni, Luisa. »Trieste and the surrounding areas«. V Musik und ihre gesellschaftliche Bedeutung nach 1945 (working title), urednik Rüdiger Ritter. Wiesbaden: Harrasowitz Verlag, 2020.

Arbo, Alessandro. Musicisti di frontiera. Gorica: Edizioni La laguna, 1998.

Becker, Tobias. »Globalizing operetta before the First World War«. The Opera Quarterly 33, št. 1 (2017): 7-27. https://doi.org/10.1093/oq/kbxo14.

Carrer, Luisa. »La Favilla (1836-1846): giornale triestino di scienze, lettere, arti, varietà e teatri«. Diplomska naloga, Univerza v Padovi, 1998-1999.

Cvetko, Ciril. Mirko Polič, dirigent in skladatelj. Ljubljana: Slovenski gledališki in filmski muzej, 1995.

Debelli Turk, Lida, ur. Sv. Jakob, zgodovinski razgledi po življenju Slovencev v tržaškem delavskem okraju. Trst: Založništvo tržaškega tiska, 1980. 
Dugulin, Adriano. »Il fascino dell'operetta«. V Tu che m'hai preso il cuor, l'operetta da Trieste all'Europa, urednik Adriano Dugulin. Trst: Občina Trst, 1994.

Edinost (Trst), 1901, 1909, 1910, 1911.

Enciclopedia monografica del Friuli Venezia Giulia. Videm: Istituto per l'Enciclopedia del FVG, 1981.

Frelih, Darja. »Viktor Parma: raziskovalna izhodišča«. Muzikološki zbornik 29 (1993):39-58.http://www.dlib.si/?URN=URN:NBN:SI:DOC-WYC4CCF7.

Il Lavoratore, 1917.

Jevnikar, Martin. „Sancin Kazimir«. V Primorski slovenski biografski leksikon, vol. 13, urednik Martin Jevnikar, 289. Gorica: Goriška Mohorjeva družba, 1987. http://www.sistory.si/cdn/publikacije/1-10oo/269/Primorski_slovenski_biografski_leksikon_13.pdf.

Lamb, Andrew. »Two Hundred Years of Maestro Campanone«. Zarzuela.net, 17. maj 2010. https://www.zarzuela.net/ref/feat/campanone.htm.

Lettelier, Robert Ignatius. Operetta: A sourcebook, vol. 1. Cambridge: Scholars Publishing, 2015.

Lettelier, Robert Ignatius. Operetta: A sourcebook, vol. 2. Cambridge: Scholars Publishing, 2015.

Licciardi, Fabiana. Theater-Kino-Varieté nella Prima guerra mondiale, l'industria dell'intrattenimento in una città al fronte: Trieste 1914-1918. Trst: EUT edizioni Università di Trieste, 2019.

Lugnani, Silvana de. La cultura tedesca a Trieste dalla fine del 1700 al tramonto dell'Impero asburgico. Trst: Edizioni Italo Svevo, 1986.

Mariborski večernik »Jutra«, 1932.

Mlakar, Slavica. Gabrijela Mrak, tolminska operna pevka. Tolmin: Knjižnica Cirila Kosmača, 1999.

Moravec, Dušan, ed. Repertoar slovenskih gledališč 1867-1967. Ljubljana: Slovenski gledališki muzej, 1967.

Neubauer, Henrik. Opereta v Sloveniji, zgodovinski pregled. Ljubljana: Glasbena matica, 2008.

Nordio, Mario. Il Politeama Rossetti di Trieste, storia di cinquant'anni 18781928. Trst: Direzione del teatro, 1928.

Petronio, Marina. L'operetta a Trieste... e altra musica d'intrattenimento. Trst: Luglio editore, 2010. 
Potočnik, Dragan. »Primorski Slovenci v Mariboru 1918-1941«. Annales 21, št. 1 (2011): 55-70.

Premru, Lado. »Slovensko petje pri Sv. Jakobu«. Jadranski koledar 1976, 223-33. Runti, Carlo. Sull'onda del Danubio blu. Trst: Edizioni LINT, 1985.

Slovan 1, št. 7 (14. februar 1884): 53. http://www.dlib.si/?URN=URN:NBN:SI: doc-OAFEO8TH. 